\title{
Contemporary Belarusian Literature
}

\author{
BY \\ ARNOLD MCMILLIN* \\ Biaźliepkina, Aksana. \\ 100 sloŭ pra sučasnuju bielaruskuju litaraturu (100 Words about Contemporary \\ Belarusian Literature), Limaryus: Minsk, 2012, 224 pp. Bibliography. Index of \\ Names. \\ 45,000 BYR (paperback) \\ ISBN 9789856968276.
}

Belarusian literary criticism has improved radically since the fall of the Soviet Union, and Aksana Biaźliepkina has made a significant contribution to the corpus of new writing on the Belarusian literary process. Hitherto best known for her excellent account of the Tutejšyja group (Razam i paasobku: Tavarystva $<$ Tutejšyja>: Historyja, asoby, žanry, Minsk: Bielaruski knihazbor, 2003), she has published widely, particularly in gender and literary studies.

Her 'hundred words' is in fact a hundred short articles of about two pages in length, each followed by a note of other literary works and books that have relevance to the particular topic (Lit.), references to secondary literary (Bibl.) and, finally, indications to other related parts of the book. A welcome feature is the very extensive Index of Names, although in a book of greater compass (almost certainly not an option for the author) an amalgamated bibliography at the end would have been a welcome enhancement. As it is, various works by the same critic may be cited for different articles, which might not matter in many cases, but in, for example, the article on Criticism (Krytyka, pp. 83-84) only an early work by prominent critic Hanna Kiślicyna (Blonde Bombshell, 2003) is cited, although an arguably more relevant book for this article, her Novaja literaturnaja situacyja: Źmiena kulturnaj paradyhmy (2006), appears earlier with the article on Bum-Bam-Lit (pp. 31-32). Also in 'Krytyka' the latest book by Iryna Šaŭliakova, Sapraŭdnyja chroniki Poŭni (2011) is cited, but her earlier books

\footnotetext{
* Arnold McMillin is Emeritus Professor at the School of Slavonic and East European Studies, University College London.
} 
(Sientymientaĺnaje paliavańnie [2000] and Restaŭracyja ščyraści [2005]), appear later or not at all.

The purpose of this review is not, however, to suggest what might have been but to note gratefully what we have. For this encylopaedic work Biaźliepkina has read widely, consulting in addition to primary texts and secondary sources, aŭtarefieraty (dissertation abstracts) and publications of conference proceedings. The chronological range of 100 sloŭ is roughly the last twenty-five years, from 1987 to 2012, but some topics of necessity go beyond this span: for example, Socialist Realism, and Vasiĺ Bykaŭ (1924-2013) or Uladzimir Karatkievič (19301984). The latter are two of a total of eight writers featured individually, the others being Uladzimier Arloŭ, Adam Hlobus, Aleś Razanaŭ. Anatoĺ Sys, Andrej Fiedarenka and Andrej Chadanovič. Possibly obvious omissions are national poet Ryhor Baradulin (1935-2014), who has published many books since 1987, and Uladzimir Niaklajeŭ, whose name may be too hot to be given prominence in the book's contents, although both poets are referred to in several articles. This case is a reminder, if one be needed, of the constantly changing situation in Belarus, not least in culture. Since the appearance of Biaźlepkina's valuable compilation in late 2012, one of the main independent Belarusian publishers, Lohvinaŭ, has fallen under the axe.

Following 'Krytyka' is 'Komiks' (Comics), one of the more surprising entries: initially dominated by Japan and the United States, comics entered Belarusian quasi-literary space in the electronic age, one early example being an internet comic by Hlobus and Uladzimir Siǔčykaŭ loosely based on Karatkievič's evergreen Dzikaje paliavańnie Karalia Stacha (King Stach's wild hunt). Other Belarusian comics include some attempts to address young children, an early and influential example being Pryhody kapitana Tanaki (The adventures of Captain Tanaki, 2009). Preceding 'Komiks' is 'Klasičnaja litaratura' (Classical literature), which begins its survey with Kupala and Bahdanovič and ends with various uses of the classics as objects for jeux d'esprit (for instance by Anka Upala), and as a source of characters for detective stories (the latter genre is the subject of another article), notably by Maksim Klimkovič and Miraslaŭ Adamčyk. Women's writing is accorded more attention than is usual in most surveys of Belarusian literature: there are sensitive and wide-ranging articles on women's poetry, women's prose, and the image of women in Belarusian literature generally.

In some articles such as 'Bajka' (The fairy story), 'Balada' (The ballad) and 'Vierlibr' (Free verse), the author is in direct competition with other compendia like, for instance, V.P. Rahojša's Litaraturaznaǔčy sloŭnik of 2009, but with arti- 
cles such as those on 'Viĺnia', 'Hieroj sučasnaj bielaruskaj litaratury' (The hero of contemporary Belarusian literature), 'Detektyŭnaja proza' (Detective prose) or 'Huĺnia ŭ litaratury' (Ludic literature), to name but four, Biaźliepkina is breaking new ground.

Aksana Biaźliepkina's carefully researched new book is modestly priced (c. $\$ 5$ ). Small in size but encyclopaedic in compass, it will undoubtedly be very useful to many people from school children to students and teachers, and should also interest both scholars and writers, as well as the Belarusian cultural elite who still maintain a keen interest in all aspects of their native literature. 